\title{
In silico molecular docking and in vitro analysis of ethanolic extract Ocimum sanctum Linn.: Inhibitory and apoptotic effects against non- small cell lung cancer
}

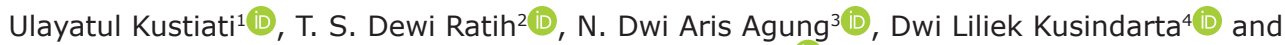 \\ Hevi Wihadmadyatami ${ }^{4}$ (i)
}

1. Post Graduate Student of Sain Veteriner, Faculty of Veterinary Medicine, Universitas Gadjah Mada, Yogyakarta, 55281, Indonesia; 2. Department of Biology, Faculty of Mathematics and Natural Sciences, and Research center of Smart Molecule of Natural Genetics Resources, Brawijaya University, Indonesia; 3. Department of Pharmacology, Faculty of Medicine, Universitas Gadjah Mada, Yogyakarta, 55281, Indonesia; 4. Department of Anatomy, Faculty of Veterinary Medicine, Universitas Gadjah Mada, Yogyakarta, 55281, Indonesia.

Corresponding author: Hevi Wihadmadyatami, e-mail: heviwihadmadyatami@ugm.ac.id Co-authors: UK: ulayatulk@gmail.com, TSDR: dratih303@gmail.com, NDAA: dwi.aris.a@ugm.ac.id, DLK: indarta@ugm.ac.id

Received: 28-06-2021, Accepted: 01-11-2021, Published online: 28-12-2021

doi: www.doi.org/10.14202/vetworld.2021.3175-3187 How to cite this article: Kustiati U, Dewi Ratih TS, Dwi Aris Agung N, Kusindarta DL, Wihadmadyatami H (2021) In silico molecular docking and in vitro analysis of ethanolic extract Ocimum sanctum Linn.: Inhibitory and apoptotic effects against non-small cell lung cancer, Veterinary World, 14(12): 3175-3187.

\begin{abstract}
Background and Aim: Lung cancer, especially non-small cell lung cancer (NSCLC), has been identified as the leading cause of cancer deaths worldwide. The mortality rate from lung cancer has been estimated to be $18.4 \%$. Until now, conventional treatments have not yielded optimal results, thus necessitating an investigation into the use of traditional herbal plants as potential candidates for its treatment. This study aimed to determine the inhibitory and apoptotic activity of the ethanolic extract from Ocimum sanctum Linn. (EEOS) by in silico molecular docking and through in vitro studies using NSCLC cells (A549 cell line).
\end{abstract}

Materials and Methods: Dried simplicia of Ocimum sanctum was converted into EEOS using the maceration method. Spectrophotometry was then employed to analyze the EEOS compound. The known main active compounds were further analyzed for inhibitory and apoptotic effects on gene signaling using in silico molecular docking involving the downloading of active compounds from PubChem and target proteins from the Protein Data Bank; the active compounds and proteins were then prepared using the Discovery Studio software v. 19.0.0 and the PyRX 0.8 program, interacted with the HEX 8.0.0 program, and visualized with the Discovery Studio Visualizer v. 19.0. Finally, an in vitro analysis was performed using an antiproliferativecytotoxic test (3-(4,5-dimethylthiazolyl-2)-2,5-diphenyltetrazolium bromide assay in the NSCLC A549 cell line).

Results: The analysis revealed that the active compounds in the ethanolic extract were dominated by quercetin (flavonoids) $(47.23 \% \mathrm{~b} / \mathrm{b})$ and eugenol (phenolic) $(12.14 \% \mathrm{~b} / \mathrm{b})$. These active compounds interacted with the active sites (residual amino acids) of the $\alpha v \beta 3$ integrin, $\alpha 5 \beta 1$ integrin, caspase-3, caspase- 9 , and vascular endothelial growth factor. Hydrogen bonds and Pi-cation and Pi-alkyl interactions were involved in the relationships between the active compounds and the active sites and thus may reveal an antioxidant property of the extract. Furthermore, in vitro analysis showed the inhibitory and antiproliferative effects of the EEOS against non-small cell cancer (A549).

Conclusion: Taken together, our data showed the ability of EEOS as an inhibitor and apoptotic agent for lung cancer; however, further research is needed to determine the exact mechanism of EEOS as an herbal medication.

Keywords: in vitro, lung cancer, molecular docking, Ocimum sanctum.

\section{Introduction}

Non-small cell lung cancer (NSCLC), a type of lung cancer, has been determined to be a significant cause of cancer death worldwide. Data from the Global Cancer Statistics show that the mortality rate due to lung cancer was $18.4 \%$ in 2018 , with 1.8 million deaths and 2.1 million new lung cancer cases

Copyright: Kustiati, et al. Open Access. This article is distributed under the terms of the Creative Commons Attribution 4.0 International License (http://creativecommons.org/licenses/ by/4.0/), which permits unrestricted use, distribution, and reproduction in any medium, provided you give appropriate credit to the original author(s) and the source, provide a link to the Creative Commons license, and indicate if changes were made. The Creative Commons Public Domain Dedication waiver (http:// creativecommons.org/publicdomain/zero/1.0/) applies to the data made available in this article, unless otherwise stated. recorded [1]. Lung cancer is deemed the most fatal compared with other types of cancer. Although lung cancer is strongly correlated with smoking, adenocarcinoma of NSCLC can also occur in non-smokers, thus increasing the prevalence of lung cancer in all populations.

At present, most lung cancer treatments involve conventional therapy approaches (chemotherapy/ medication and surgery). Standard medication therapy in the treatment of NSCLC cases is the use of cisplatin in combination with pemetrexed [2]. In addition, treatment with antibody engineering systems such as pembrolizumab, nivolumab, and atezolizumab is now actively used $[3,4]$; however, the administration of these drugs has been noted to have drawbacks. 
Aside from being expensive, these drugs induce a chemoresistant effect that appears in the treatment of lung and breast cancer. In addition, pembrolizumab and nivolumab are known to cause oral mucositis, rush, and pruritus caused by immune-related adverse effects $[3,5]$. Combination therapy such as radiotherapy with pembrolizumab is known to have side effects that increase the drug's toxic effect [5].

Because of the disadvantages of these medications, there is a need to explore natural herbal traditional remedies. The system of traditional medicine has been used for thousands of years to prevent, diagnose, and treat several acute and chronic diseases. Ocimum sanctum Linn. is a traditional medicine commonly found in Indonesia and Asian countries. Various species of Ocimum are known to provide many health benefits, including anti-inflammatory, anti-fatigue, antitussive, antiseptic, antispasmodic, neuroprotective, and neuroproliferative activities [6-11], but until recently, their active mechanisms, safety, and dosage have not been determined.

Thus, in this study, we aimed to determine the dynamic majority content of the ethanolic extract from $O$. sanctum Linn. (EEOS) and analyze the extract's effect against NSCLC by in silico molecular docking and in vitro studies.

\section{Materials and Methods \\ Ethical approval}

The study was approved by the Ethics Committee of the Faculty of Veterinary Medicine, Universitas Gadjah Mada, Yogyakarta, Indonesia (00053/EC/ FKH/Int./2021).

\section{Study period and location}

The study was conducted from January to June 2021 at the Department of Pharmacology Faculty of Medicine, Public Health, and Nursing and Integrated Laboratory for Research and Testing Laboratory, Universitas Gadjah Mada

\section{Preparation of ethanolic extract}

$O$. sanctum Linn. leaves and dried simplicia were derived from the herbal company $\mathrm{CV}$ Merapi Farma Herbal, Yogyakarta, Indonesia. The leaves were identified at the Laboratory of Plant Systematics, Faculty of Biology, Universitas Gadjah Mada. The dried simplicia was then made into an ethanolic extract at the Integrated Laboratory for Research and Testing, Universitas Gadjah Mada. The ethanolic extracts were made using the maceration technique. A volume of $4000 \mathrm{~mL}$ of ethanol $96 \%$ (Merck) was added to the simplicia of $O$. sanctum, which weighed as much as $300.12 \mathrm{~g}$. The mixture was stirred for $30 \mathrm{~min}$, allowed to stand $48 \mathrm{~h}$, and then filtered twice. The filtrate was evaporated using a vacuum rotary evaporator (Buchi, Flawil, Switzerland) and heated in a water bath (Memmert, Schwabach, Germany) at $60^{\circ} \mathrm{C}$. The thick extract was poured into a porcelain cup and heated in a water bath at $70^{\circ} \mathrm{C}$ with occasional stirring. A final extract weight of $26.48 \mathrm{~g}$ of $O$. sanctum leaf extract was obtained.

\section{Spectrophotometry analysis}

\section{Flavonoid}

EEOS, weighing $50 \mathrm{mg}$, was placed into a $10 \mathrm{~mL}$ test tube, in which $0.3 \mathrm{~mL}$ of $5 \%$ sodium nitrite (Merck) was subsequently added. After $5 \mathrm{~min}, 0.6 \mathrm{~mL}$ of $10 \%$ aluminum chloride (Merck) and $2 \mathrm{~mL}$ of $1 \mathrm{M}$ sodium hydroxide (Merck) were added to the solution along with the addition of up to $10 \mathrm{~mL}$ of distilled water. The mixture was then transferred into a cuvette and measured through spectrophotometry (Shimadzu, Kyoto, Japan) at a wavelength of $510 \mathrm{~nm}$. Quantification of the total compound was calculated using the following formula:

$$
\begin{aligned}
& \begin{array}{l}
\text { value }(\mathrm{ppm}) \times \\
\text { end volume }(\mathrm{mL}) \times \\
\text { total compound } \\
(\% \mathrm{~b} / \mathrm{b})
\end{array}=\frac{\text { dilution factor }}{\text { weight of sample }(\mathrm{g})} \times 100 \%
\end{aligned}
$$

\section{Phenol}

The EEOS weighed $50 \mathrm{mg}$. To the extract, $0.5 \mathrm{~mL}$ of Folin-Ciocalteu (Merck) reagent and $7.5 \mathrm{~mL}$ of aquabides were added. The mixture was allowed to stand for $10 \mathrm{~min}$ at $24^{\circ} \mathrm{C}$ followed by the addition of $1.5 \mathrm{~mL}$ of $20 \%$ sodium carbonate (Merck). Sterile water was then added to achieve a final volume of $10 \mathrm{~mL}$. The solution mixture was transferred into a cuvette and measured on a spectrophotometer (Shimadzu) at a wavelength of $760 \mathrm{~nm}$. Quantification of the total compound was calculated using the following formula:

$$
\begin{aligned}
& \begin{array}{l}
\text { value }(\mathrm{ppm}) \times \\
\text { end volume }(\mathrm{mL}) \times \\
\text { total compound } \\
(\% \mathrm{~b} / \mathrm{b})
\end{array}=\frac{\text { dilution factor }}{\text { weight of sample }(\mathrm{g})} \times 100 \%
\end{aligned}
$$

\section{In silico molecular docking}

\section{Bioactive compound preparation}

The two bioactive compounds with the largest amounts in the EEOS were identified as eugenol (CID_3314) and quercetin (CID_5280343), downloaded from PubChem database (https://pubchem. ncbi.nlm.nih.gov/).

\section{Protein target preparation}

The target proteins used in this in silico study were integrin $\alpha v \beta 3$ (Protein Data Bank [PDB] ID: $4 \mathrm{~g} 1 \mathrm{e}$ ), integrin $\alpha 5 \beta 1$ (PDB ID: 3vi3), caspase-9 (PDB ID:1jxq), caspase-3 (PDB ID: 1nms), and vascular endothelial growth factor (VEGF) (PDB ID: 
3v2a), which were downloaded from the Structural Information PDB (https://www.rcsb.org/ligand/).

\section{Molecular docking analysis}

Bioactive compounds (flavonoids and phenols) and target proteins (integrin $\alpha v \beta 3$, integrin $\alpha 5 \beta 1$, caspase-9, caspase- 3 , and VEGF) were prepared sequentially using the Discovery Studio v. 19.0.0 program (https://www.3ds.com/ products-services/biovia/) and the PyRX 0.8 program. The proteins and bioactive compounds were interacted with the HEX 8.0.0 program (http:// hex.loria.fr/) and visualized with the Discovery Studio Visualizer v. 19.0.0 (https://www.3ds.com/ products-services/biovia/).

\section{Maintenance of the NSCLC (A549) cell line}

The NSCLC cells (A549 cell line) were generously gifted by Prof. Dr. Srikanth Karnati (Wuerzburg, Germany). The cells were cultured in the complete growth medium, Dulbecco's Modified Eagle Medium (Gibco, New York, USA) containing 10\% fetal calf serum (Capricorn Scientific, Ebsdorfergrund, Germany), penicillin-streptomycin (Capricorn Scientific), and amphotericin (Gibco). The cells were maintained at $37^{\circ} \mathrm{C}$ in a $5 \% \mathrm{CO}_{2}$ incubator.

\section{Cell proliferation assay (3-(4,5-dimethylthi- azolyl-2)-2,5-diphenyltetrazolium bromide [MTT] assay)}

The inhibitory activity of the EEOS was examined using an MTT assay. Cells that reached an $80 \%$ confluence in culture were detached with $1 \mathrm{~mL}$ of Accutase cell detachment (Capricorn Scientific). The cells were then inserted into a $15 \mathrm{~mL}$ sterile conical tube and centrifuged at $1500 \mathrm{rpm}$ for $5 \mathrm{~min}$. The supernatants were removed, and the cells were counted using a cell counter (Corning, New York, USA). Then, NSCLC (A549) cells were seeded onto a 96-well plate at a density of $1.5 \times 10^{4}$ cells/ well and incubated overnight at $37^{\circ} \mathrm{C}$. Afterward, the cells were cultured with the AP3 monoclonal antibody at a concentration of $80 \mu \mathrm{g} / \mathrm{mL}$ as the antiproliferative positive control. In addition, $9 \mu \mathrm{g} / \mathrm{mL}$ cisplatin was run as the positive control of a commercial drug used to treat lung cancer. Furthermore, the EEOS was added in increasing concentrations $(50,70,100$, and $200 \mu \mathrm{g} / \mathrm{mL})$. The cells were incubated for $24 \mathrm{~h}$, washed with Dulbecco's phosphate buffer saline (Capricorn Scientific) followed by 10 $\mu \mathrm{L}$ of $5 \mu \mathrm{g} / \mathrm{mL}$ MTT (Merck), and incubated in the $\mathrm{CO}_{2}$ incubator (Eppendorf, Hamburg, Germany) for $4 \mathrm{~h}$ at $37^{\circ} \mathrm{C}$ and $5 \% \mathrm{CO}_{2}$. Finally, the medium was removed, and $100 \mu \mathrm{L}$ of $95 \%$ sodium dodecyl sulfate $10 \%$ (Merck) was added to dissolve the formazan crystals. Optical density values were obtained using a microplate reader (Bio-Rad, California, USA) at $595 \mathrm{~nm}$. Inhibition of the A549 cell line samples was calculated using the following formula:

$$
\text { cell viability }(\%)=\frac{\begin{array}{l}
\text { treated abs }- \\
\text { negative control abs } \\
\text { nontreated cell abs - } \\
\text { negative control abs }
\end{array} 100 \%}{}
$$

\section{Observation of cell morphology}

The NSCLC (A549) cells were seeded onto 6-well plates (at $5 \times 10^{5}$ cells $/ \mathrm{mL}$ ) for $24 \mathrm{~h}$ and then treated with $80 \mu \mathrm{g} / \mathrm{mL}$ of the AP3 monoclonal antibody inhibitor as the positive control, followed by $9 \mu \mathrm{g} / \mathrm{mL}$ of cisplatin as the commercial drug positive control, and the EEOS at increasing concentrations of $50,70,100$, and $200 \mu \mathrm{g} / \mathrm{mL}$ for $24 \mathrm{~h}$. The morphology of the cells was observed and photographed using a bright-field microscope (Nikon Eclipse TE2000-E, Tokyo, Japan). The observation data were analyzed semi-quantitatively.

\section{Statistical analysis}

The data obtained were analyzed using a oneway analysis of variance followed by a post hoc test by GraphPad Prism software v. 7 (La Jolla, CA, USA).

\section{Results}

\section{Eugenol and quercetin are the dominant components} in the EEOS

The experimental analysis using an ultraviolet-visible spectrophotometer showed that EEOS consisted mostly of the active compound of flavonoid derivatives, that is, quercetin $(47.23 \% \mathrm{~b} / \mathrm{b})$, and phenol derivatives, that is, eugenol $(12.14 \% \mathrm{~b} / \mathrm{b})$ (Table- 1$)$.

\section{Quercetin binds to the active sites of integrins $\alpha 5 \beta 3$ and $\alpha 5 \beta 1$}

Four amino acid residues depict the binding of quercetin and integrin $\alpha v \beta 3$ at Lys409, Arg261, Tyr224, Arg99, and Ser160, yielded bond energy of $257.3 \mathrm{~kJ} / \mathrm{mol}$ (Figure-1 and Table-2). Meanwhile, the interaction between quercetin and integrin $\alpha 5 \beta 1$ showed five interacting amino acid residues (Thr258, Gly255, Asn256, Leu257, and Ser277) and yielded bond energy of $-226.1 \mathrm{~kJ} / \mathrm{mol}$ (Figure-2 and Table-2). The bonding between quercetin and $\alpha v \beta 3$ and $\alpha 5 \beta 1$ occurred through hydrogen and carbon-hydrogen bonds (Table-2).

\section{Chemical interactions occurred between quercetin and caspase- $3 /$ caspase- 9}

The interaction of caspase- 3 with quercetin showed six amino acid residues bind to the amino acid residues of quercetin, namely, Thr270, Arg241, Thr152,

Table-1: Bioactive compounds with the largest composition contained in the ethanolic extract of Ocimum

\begin{tabular}{|c|c|c|c|c|}
\hline No. & $\begin{array}{l}\text { Name of } \\
\text { compound }\end{array}$ & Concentration & Unit & Method \\
\hline 1. & $\begin{array}{l}\text { Quercetin } \\
\text { (Flavonoid) }\end{array}$ & 47,23 & $\% b / b$ & $\begin{array}{l}\text { Spectrophotometry } \\
\text { UV-Vis }\end{array}$ \\
\hline 2. & $\begin{array}{l}\text { Eugenol } \\
\text { (Phenol) }\end{array}$ & 12,14 & $\% b / b$ & $\begin{array}{l}\text { Spectrophotometry } \\
\text { UV-Vis }\end{array}$ \\
\hline
\end{tabular}
sanctum Linn. 


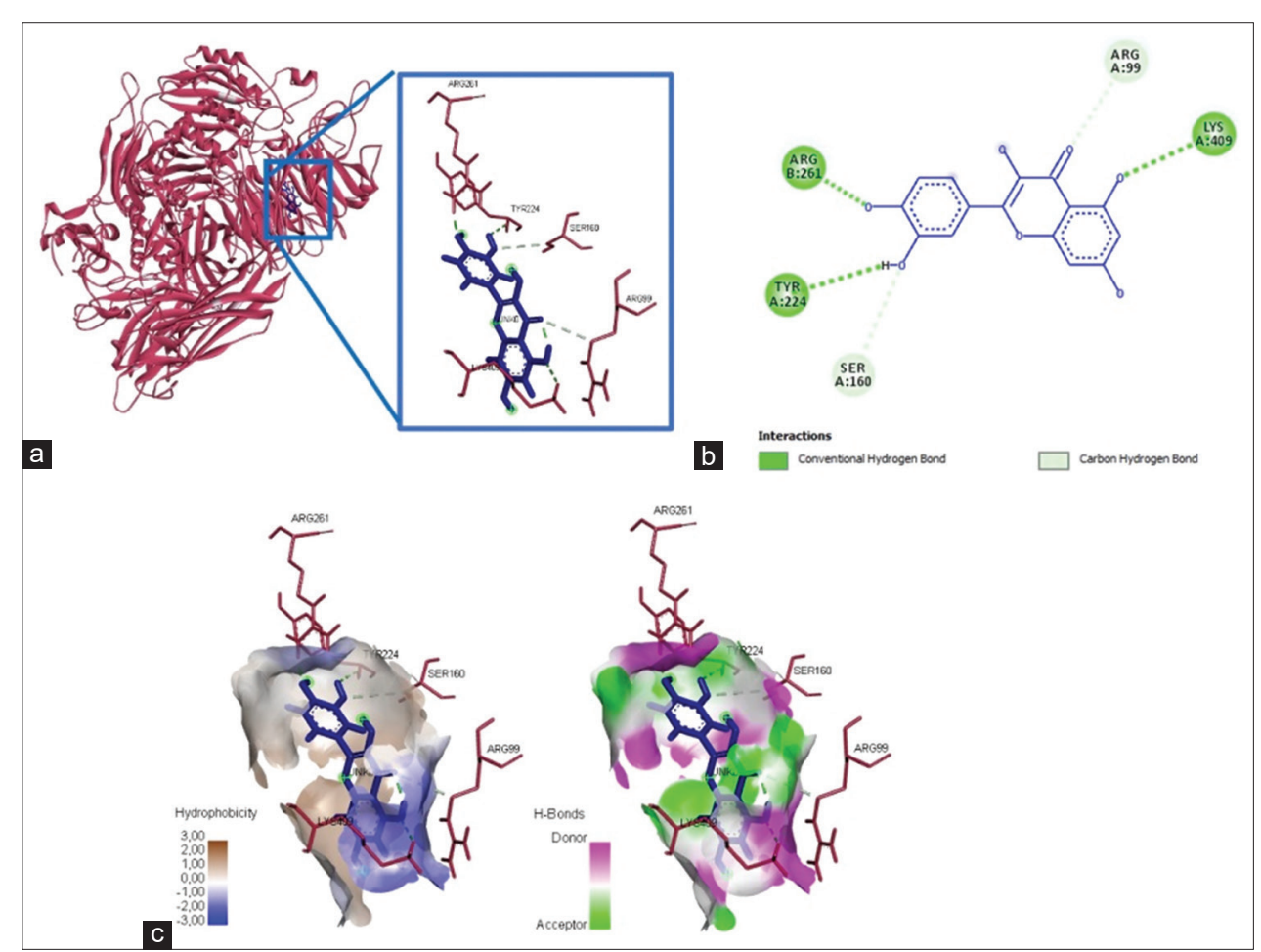

Figure-1: The three-dimensional and two-dimensional structure of the interaction between flavonoid compounds (quercetin) and $\alpha v \beta 3$ integrins. (a) Three-dimensional structural interaction between flavonoid-ligand compound quercetin (blue) against $\alpha v \beta 3$ integrins on the active binding site (red). (b) This interaction is established by hydrogen and carbonhydrogen bonds on the active site of the $\alpha \mathrm{v} \beta 3$ integrin, namely, Arg99, Arg261, Tyr224, and Lys409, which can be seen in the two-dimensional (b) and three-dimensional (c) structures.

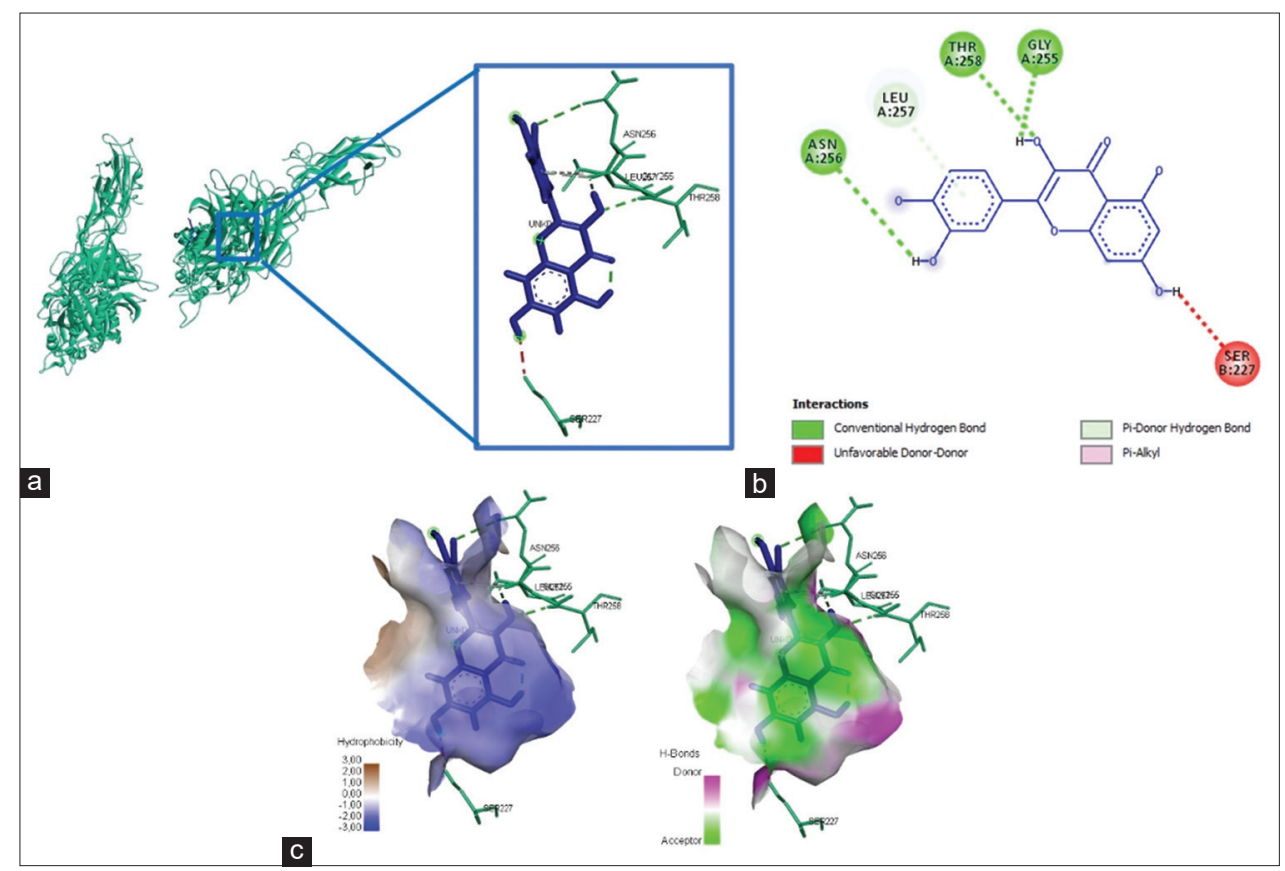

Figure-2: The three-dimensional and two-dimensional structure of the interaction between flavonoid compounds (quercetin) and $\alpha 5 \beta 1$ integrins. (a) Three-dimensional structural interaction between flavonoid-ligand compound quercetin (blue) against integrin $\alpha 5 \beta 1$ on the active binding site (green). (b) This interaction is built by hydrogen and carbonhydrogen bonds on the active site of the $\alpha 5 \beta 1$ integrin, namely, Thr258, Gly255, Asn256, Leu257, and Ser277, which can be seen in the two-dimensional (b) and three-dimensional (c) structures.

Gly153, Lys271, and Ile187, with total energy formed of $-262.9 \mathrm{~kJ} / \mathrm{mol}$ (Figure-3 and Table-2). In addition, quercetin bound to caspase- 9 at the amino acid residue Glu187 and yielded energy of $-115.8 \mathrm{~kJ} / \mathrm{mol}$ (Figure-4 and Table2). The interaction between quercetin and caspase- 3 and caspase- 9 was formed by hydrogen bonds and Pi-cation, P-sigma, and Pi-alkyl interactions (Table-2).

\section{Quercetin binds to the active site of VEGF}

Quercetin interacted with the amino acid residues in VEGF, namely, Gln79, Pro49, and Lys48, 
Table-2: Interaction, chemical bond, and binding energy between quercetin and integrins $\alpha \mathrm{V} \beta 3$, integrins $\alpha 5 \beta 1$, Caspase-3, Caspase-9, and VEGF.

\begin{tabular}{|c|c|c|c|c|c|c|c|}
\hline Ligands & Protein & $\begin{array}{l}\text { Binding } \\
\text { energy } \\
(\mathbf{k J} / \mathrm{mol})\end{array}$ & $\begin{array}{l}\text { Point } \\
\text { Interactions }\end{array}$ & Category & Type & Donor & Acceptor \\
\hline \multirow[t]{6}{*}{ Quercetin } & $\alpha \vee \beta 3$ & $-257,3$ & $\begin{array}{l}\text { A: LYS409:HZ2 } \\
- \text { :UNK0:O3 }\end{array}$ & Hydrogen Bond & $\begin{array}{l}\text { Conventional } \\
\text { Hydrogen Bond }\end{array}$ & A: LYS409:HZ2 & :UNK0:O3 \\
\hline & & & $\begin{array}{l}\text { B: ARG261:HH11 } \\
- \text { :UNK0:O7 }\end{array}$ & Hydrogen Bond & $\begin{array}{l}\text { Conventional } \\
\text { Hydrogen Bond }\end{array}$ & $\begin{array}{l}\text { B: } \\
\text { ARG261:HH11 }\end{array}$ & :UNK0:O7 \\
\hline & & & $\begin{array}{l}\text { :UNKO:H29 } \\
-: \text { UNKO:O4 }\end{array}$ & Hydrogen Bond & $\begin{array}{l}\text { Conventional } \\
\text { Hydrogen Bond }\end{array}$ & :UNKO:H29 & :UNK0:04 \\
\hline & & & $\begin{array}{l}\text { :UNK0:H31 - A: } \\
\text { TYR224:O }\end{array}$ & Hydrogen Bond & $\begin{array}{l}\text { Conventional } \\
\text { Hydrogen Bond }\end{array}$ & :UNKO:H31 & A: TYR224:0 \\
\hline & & & $\begin{array}{l}\text { A: ARG99:CD } \\
-: \text { UNK0:04 }\end{array}$ & Hydrogen Bond & $\begin{array}{l}\text { Carbon Hydrogen } \\
\text { Bond }\end{array}$ & A: ARG99:CD & :UNK0:O4 \\
\hline & & & $\begin{array}{l}\text { A: SER160:CB } \\
-: \text { UNK0:06 }\end{array}$ & Hydrogen Bond & $\begin{array}{l}\text { Carbon Hydrogen } \\
\text { Bond }\end{array}$ & A: SER160:CB & :UNK0:06 \\
\hline \multirow[t]{7}{*}{ Quercetin } & $\alpha 5 \beta 1$ & -226.1 & $\begin{array}{l}\text { A: THR258:HN } \\
-: \text { UNK0:O2 }\end{array}$ & Hydrogen Bond & $\begin{array}{l}\text { Conventional } \\
\text { Hydrogen Bond }\end{array}$ & A: THR258:HN & :UNK0:02 \\
\hline & & & $\begin{array}{l}\text { :UNKO:H28 - A: } \\
\text { GLY255:O }\end{array}$ & Hydrogen Bond & $\begin{array}{l}\text { Conventional } \\
\text { Hydrogen Bond }\end{array}$ & :UNKO:H28 & A: GLY255:O \\
\hline & & & $\begin{array}{l}\text { :UNK0:H29 } \\
- \text { :UNK0:O4 }\end{array}$ & Hydrogen Bond & $\begin{array}{l}\text { Conventional } \\
\text { Hydrogen Bond }\end{array}$ & :UNKO:H29 & :UNK0:04 \\
\hline & & & $\begin{array}{l}\text { :UNKO:H31 - A: } \\
\text { ASN256:OD1 }\end{array}$ & Hydrogen Bond & $\begin{array}{l}\text { Conventional } \\
\text { Hydrogen Bond }\end{array}$ & :UNKO:H31 & $\begin{array}{l}\text { A: } \\
\text { ASN256:OD1 }\end{array}$ \\
\hline & & & $\begin{array}{l}\text { A: LEU257:HN } \\
-: \text { UNK0 }\end{array}$ & Hydrogen Bond & $\begin{array}{l}\text { Pi-Donor } \\
\text { Hydrogen Bond }\end{array}$ & A: LEU257:HN & :UNKO \\
\hline & & & $\begin{array}{l}\text { :UNKO - A: } \\
\text { LEU257 }\end{array}$ & Hydrophobic & Pi-Alkyl & :UNKO & A: LEU257 \\
\hline & & & $\begin{array}{l}\text { B: SER227:HG } \\
-: \text { UNK0:H30 }\end{array}$ & Unfavorable & $\begin{array}{l}\text { Unfavorable } \\
\text { Donor-Donor }\end{array}$ & B: SER227:HG & :UNK0:H30 \\
\hline \multirow[t]{9}{*}{ Quercetin } & Caspase 3 & -262.9 & $\begin{array}{l}\text { A: THR270:HG1 } \\
-: \text { UNK0:05 }\end{array}$ & Hydrogen Bond & $\begin{array}{l}\text { Conventional } \\
\text { Hydrogen Bond }\end{array}$ & A: THR270:HG1 & :UNK0:05 \\
\hline & & & $\begin{array}{l}\text { B: ARG241:HE } \\
-: \text { UNK0:O3 }\end{array}$ & Hydrogen Bond & $\begin{array}{l}\text { Conventional } \\
\text { Hydrogen Bond }\end{array}$ & B: ARG241:HE & :UNK0:03 \\
\hline & & & $\begin{array}{l}\text { :UNK0:H29 } \\
-: \text { UNK0:O4 }\end{array}$ & Hydrogen Bond & $\begin{array}{l}\text { Conventional } \\
\text { Hydrogen Bond }\end{array}$ & :UNKO:H29 & :UNK0:04 \\
\hline & & & $\begin{array}{l}\text { :UNK0:H32 - A: } \\
\text { THR152:O }\end{array}$ & Hydrogen Bond & $\begin{array}{l}\text { Conventional } \\
\text { Hydrogen Bond }\end{array}$ & :UNK0:H32 & A: THR152:O \\
\hline & & & $\begin{array}{l}\text { A: GLY153:CA } \\
-: \text { UNK0:O1 }\end{array}$ & Hydrogen Bond & $\begin{array}{l}\text { Carbon Hydrogen } \\
\text { Bond }\end{array}$ & A: GLY153:CA & :UNK0:01 \\
\hline & & & $\begin{array}{l}\text { A: LYS271:NZ } \\
-: \text { UNKO }\end{array}$ & Electrostatic & Pi-Cation & A: LYS271:NZ & :UNKO \\
\hline & & & $\begin{array}{l}\text { A: LYS271:NZ } \\
-: \text { UNKO }\end{array}$ & Electrostatic & Pi-Cation & A: LYS271:NZ & :UNKO \\
\hline & & & $\begin{array}{l}\text { A: GLY153:CA } \\
-: \text { UNK0 }\end{array}$ & Hydrophobic & Pi-Sigma & A: GLY153:CA & :UNKO \\
\hline & & & $\begin{array}{l}\text { :UNKO - A: } \\
\text { ILE187 }\end{array}$ & Hydrophobic & Pi-Alkyl & :UNKO & A: ILE187 \\
\hline \multirow[t]{2}{*}{ Quercetin } & Caspase 9 & -115.8 & $\begin{array}{l}\text { :UNKO:H29 } \\
-: \text { UNK0:O4 }\end{array}$ & Hydrogen Bond & $\begin{array}{l}\text { Conventional } \\
\text { Hydrogen Bond }\end{array}$ & :UNK0:H29 & :UNK0:04 \\
\hline & & & $\begin{array}{l}\text { B: GLU187:CG } \\
-: \text { UNK0:05 }\end{array}$ & Unfavorable & Unfavorable Bump & B: GLU187:CG & :UNK0:05 \\
\hline \multirow[t]{8}{*}{ Quercetin } & VEGF & -213.4 & $\begin{array}{l}\text { :UNKO:H28 - A: } \\
\text { GLN79:O }\end{array}$ & Hydrogen Bond & $\begin{array}{l}\text { Conventional } \\
\text { Hydrogen Bond }\end{array}$ & :UNKO:H28 & A: GLN79:O \\
\hline & & & $\begin{array}{l}\text { :UNKO:H29 } \\
-: \text { :UNKO:O4 }\end{array}$ & Hydrogen Bond & $\begin{array}{l}\text { Conventional } \\
\text { Hydrogen Bond }\end{array}$ & :UNK0:H29 & :UNK0:04 \\
\hline & & & $\begin{array}{l}\text { A: PRO49:CD } \\
-: \text { UNK0:O1 }\end{array}$ & Hydrogen Bond & $\begin{array}{l}\text { Carbon Hydrogen } \\
\text { Bond }\end{array}$ & A: PRO49:CD & :UNK0:01 \\
\hline & & & $\begin{array}{l}\text { A: LYS48:CB } \\
-: \text { UNKO }\end{array}$ & Hydrophobic & Pi-Sigma & A: LYS48:CB & :UNKO \\
\hline & & & $\begin{array}{l}\text { :UNKO - A: } \\
\text { PRO49 }\end{array}$ & Hydrophobic & Pi-Alkyl & :UNKO & A: PRO49 \\
\hline & & & $\begin{array}{l}\text { :UNKO - A: } \\
\text { PRO49 }\end{array}$ & Hydrophobic & Pi-Alkyl & :UNKO & A: PRO49 \\
\hline & & & $\begin{array}{l}\text { :UNKO - A: } \\
\text { PRO49 }\end{array}$ & Hydrophobic & Pi-Alkyl & :UNKO & A: PRO49 \\
\hline & & & $\begin{array}{l}\text { A: GLN79:O } \\
-: \text { UNK0:C17 }\end{array}$ & Unfavorable & Unfavorable Bump & A: GLN79:O & :UNK0:C17 \\
\hline
\end{tabular}




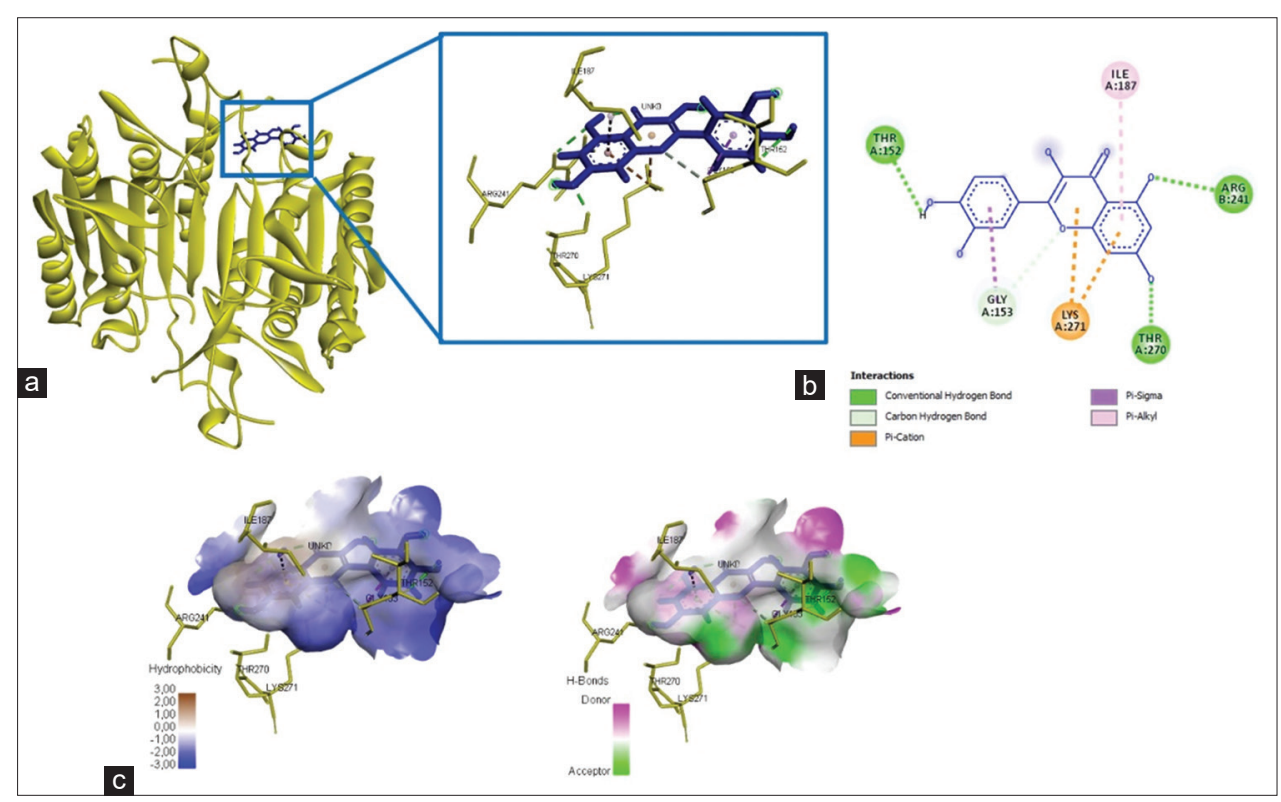

Figure-3: The three-dimensional and two-dimensional structure of the interaction between flavonoid compounds (quercetin) and caspase-3. (a) Three-dimensional structural interaction between flavonoid-ligand compound quercetin (blue) and caspase-3 on the active binding site (yellow). (b) This interaction is built by hydrogen and carbon-hydrogen bonds on the active site of caspase-3, namely, Thr270, Arg241, Thr152, Gly153, Lys271, and Ile187, which can be seen in the two-dimensional (b) and three-dimensional (c) structures.

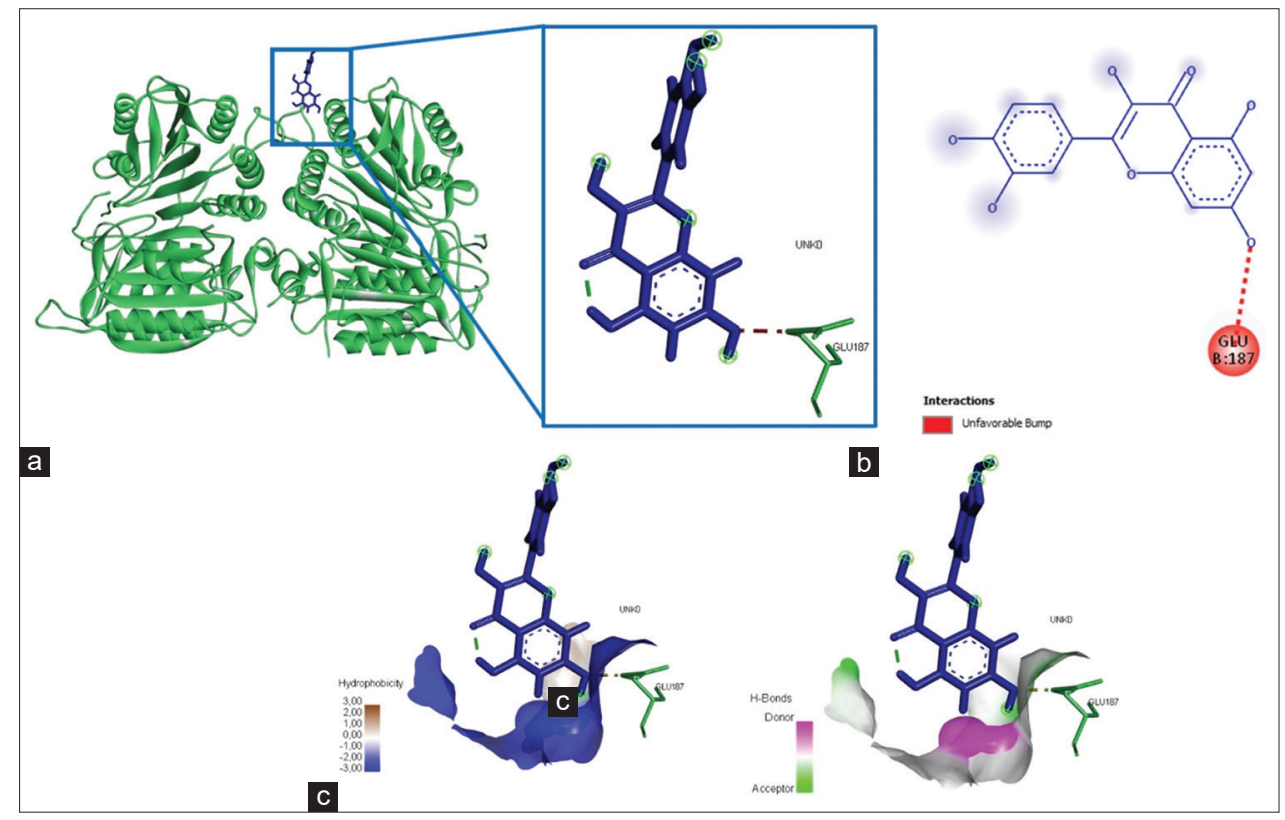

Figure-4: The three-dimensional and two-dimensional structure of the interaction between flavonoid compounds (quercetin) and caspase-9. (a) Three-dimensional structural interaction between flavonoid-ligand compound quercetin (blue) and caspase-9 on the active binding site (green). (b) This interaction is built by hydrogen and carbon-hydrogen bonds on the active site of caspase-9, namely, Glu187, which is seen in the two-dimensional (b) and three-dimensional (c) structures.

and produced energy of $-213.4 \mathrm{~kJ} / \mathrm{mol}$ (Figure-5 and Table-2). Hydrogen bonds and Pi-cation, P-sigma, and Pi-alkyl interactions were the foundation of the chemical interactions between quercetin and VEGF (Table-2).

\section{Eugenol binds to the active sites of integrins $\alpha \mathrm{v} \beta 3$ and $\alpha 5 \beta 1$}

Three amino acid residues were visualized from the interaction between eugenol and the $\alpha v \beta 3$ integrin, namely, Ser342, Tyr406, and Arg261; these bonds produced affinity energy of $181.6 \mathrm{~kJ} / \mathrm{mol}$ (Figure-6 and Table-3). Meanwhile, the active compound in eugenol only bound to $\alpha 5 \beta 1$ 's amino acid residue, Leu257, yielded energy of $-169.2 \mathrm{~kJ} / \mathrm{mol}$ (Figure-7 and Table-3). Hydrogen bonds and Pi-cation interactions established the chemical interactions between eugenol and integrins $\alpha v \beta 3$ and $\alpha 5 \beta 1$ (Table- 3 ).

\section{Chemical interactions occurred between eugenol and caspase-3/caspase-9}

The interaction of the eugenol ligand and protein caspase-3 produced one amino acid residue (Arg241) that bound the eugenol ligand (Figure-8), yielded energy of 


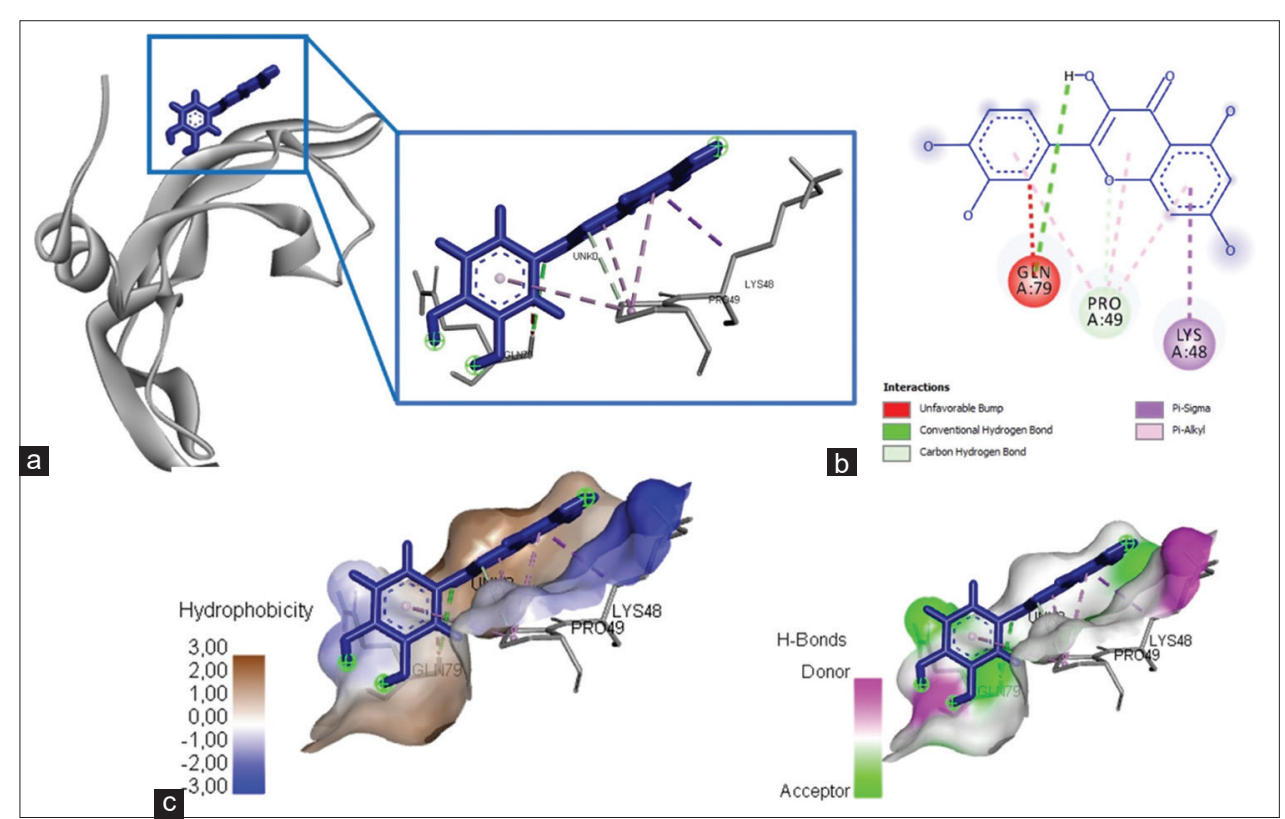

Figure-5: The three-dimensional and two-dimensional structure of the interaction between flavonoid compounds (quercetin) and vascular endothelial growth factor (VEGF). (a) Three-dimensional structural interaction between flavonoidligand compound quercetin (blue) and VEGF on the active binding site (gray). (b) This interaction is built by hydrogen and carbon-hydrogen bonds on the active sites of VEGF, namely, Gln79, Pro49, and Lys48, which can be seen in the twodimensional (b) and three-dimensional (c) structures.

Table-3: Interaction, chemical bond, and binding energy between eugenol and integrins $\alpha v \beta 3$, integrins $\alpha 5 \beta 1$, caspase-3, caspase-9, and VEGF.

\begin{tabular}{|c|c|c|c|c|c|c|c|}
\hline Ligands & Protein & $\begin{array}{c}\text { Binding } \\
\text { energy } \\
(\mathrm{kJ} / \mathrm{mol})\end{array}$ & $\begin{array}{l}\text { Point } \\
\text { Interactions }\end{array}$ & Category & Type & Donor & Acceptor \\
\hline \multirow[t]{3}{*}{ Eugenol } & $\alpha \vee \beta 3$ & -181.6 & $\begin{array}{l}\text { :UNK0:H21 - A: } \\
\text { SER342:O }\end{array}$ & Hydrogen Bond & $\begin{array}{l}\text { Carbon Hydrogen } \\
\text { Bond }\end{array}$ & :UNKO:H21 & A: SER342:O \\
\hline & & & $\begin{array}{l}\text { :UNK0:H21 - A: } \\
\text { TYR406:O }\end{array}$ & Hydrogen Bond & $\begin{array}{l}\text { Carbon Hydrogen } \\
\text { Bond }\end{array}$ & :UNK0:H21 & A: TYR406:O \\
\hline & & & $\begin{array}{l}\text { B: ARG261:NH2 } \\
-: \text { UNKO }\end{array}$ & $\begin{array}{l}\text { Hydrogen Bond; } \\
\text { Electrostatic }\end{array}$ & $\begin{array}{l}\text { Pi-Cation; } \\
\text { Pi-Donor } \\
\text { Hydrogen Bond }\end{array}$ & B: ARG261:NH2 & :UNKO \\
\hline Eugenol & $\alpha 5 \beta 1$ & -169.2 & $\begin{array}{l}\text { :UNK0:C12 - A: } \\
\text { LEU257 }\end{array}$ & Hydrophobic & Alkyl & :UNK0:C12 & A: LEU257 \\
\hline Eugenol & Caspase 3 & -184.6 & $\begin{array}{l}\text { B: ARG241:CD } \\
-: \text { UNK0:O2 }\end{array}$ & Hydrogen Bond & $\begin{array}{l}\text { Carbon Hydrogen } \\
\text { Bond }\end{array}$ & B: ARG241:CD & :UNK0:O2 \\
\hline \multirow[t]{2}{*}{ Eugenol } & Caspase 9 & -90.9 & $\begin{array}{l}\text { :UNK0:H22 - C: } \\
\text { GLU259:OE1 }\end{array}$ & Hydrogen Bond & $\begin{array}{l}\text { Conventional } \\
\text { Hydrogen Bond }\end{array}$ & :UNKO:H22 & $\begin{array}{l}\text { C: } \\
\text { GLU259:OE1 }\end{array}$ \\
\hline & & & $\begin{array}{l}\text { :UNKO - C: } \\
\text { LEU240D }\end{array}$ & Hydrophobic & Pi-Alkyl & :UNKO & C: LEU240D \\
\hline \multirow[t]{3}{*}{ Eugenol } & VEGF & -162.6 & :UNK0 - A: LEU97 & Hydrophobic & Pi-Alkyl & :UNKO & A: LEU97 \\
\hline & & & $\begin{array}{l}\text { A: GLU38:CB } \\
-: \text { UNK0:H19 }\end{array}$ & Unfavorable & Unfavorable Bump & A: GLU38:CB & :UNK0:H19 \\
\hline & & & $\begin{array}{l}\text { A: ASN75:HD22 } \\
-: \text { UNK0:H22 }\end{array}$ & Unfavorable & $\begin{array}{l}\text { Unfavorable } \\
\text { Donor-Donor }\end{array}$ & A: ASN75:HD22 & :UNKO:H22 \\
\hline
\end{tabular}

$-184.6 \mathrm{~kJ} / \mathrm{mol}$ (Table-3). Furthermore, the binding of eugenol and caspase-9 involved two amino acid residues that bound to eugenol on the active site of caspase-9, namely, Glu259 and Leu240 (Figure-9). The interaction of eugenol and caspase-9 resulted in binding energy of approximately $-90.9 \mathrm{~kJ} / \mathrm{mol}$ (Table-3). The interaction between eugenol and caspase-3/caspase-9 was established through hydrogen bonds and Pi-alkyl interactions (Table-3).

\section{Eugenol bound to the active site of VEGF}

The interaction of the eugenol compounds and the VEGF protein indicated the involvement of three amino acid residues (Leu97, Glu38, and Asn75) that interacted with the eugenol compounds through Pi-alkyl and hydrophobic interactions (Figure-10 and Table-3). This interaction yielded a bond energy of $-162 \mathrm{~kJ} / \mathrm{mol}$ (Table-3).

\section{Decreasing the viability of A549 cells in the presence of EEOS}

NSCLC cells were cultured to evaluate the ability of EEOS to inhibit the cells' proliferation and adhesion to the extracellular matrix. Our results showed that EEOS significantly exhibited a cytotoxic 


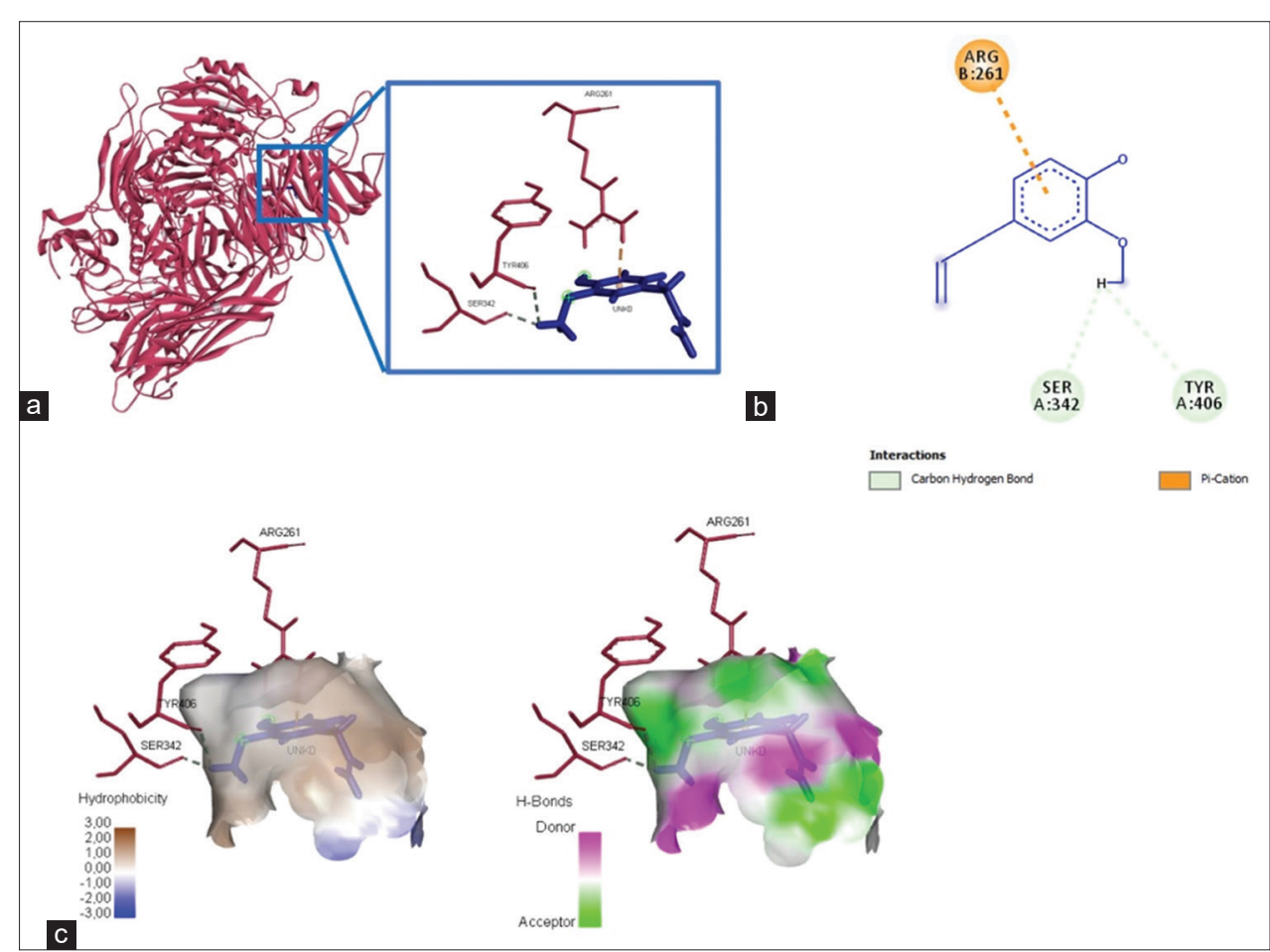

Figure-6: The visualization of the three-dimensional and two-dimensional interaction between phenolic compounds (eugenol) and integrin $\alpha v \beta 3$. (a) Three-dimensional structural interaction between phenol-ligand eugenol compounds (blue) and integrin $\alpha v \beta 3$ (red). (b) This interaction is established by hydrophobic hydrogen bonds (green) and aromatic bonds (yellow) on the active site of the vb3 integrin, namely, Ser342, Tyr406, and Arg261, which can be seen in the twodimensional (b) and three-dimensional (c) structures.

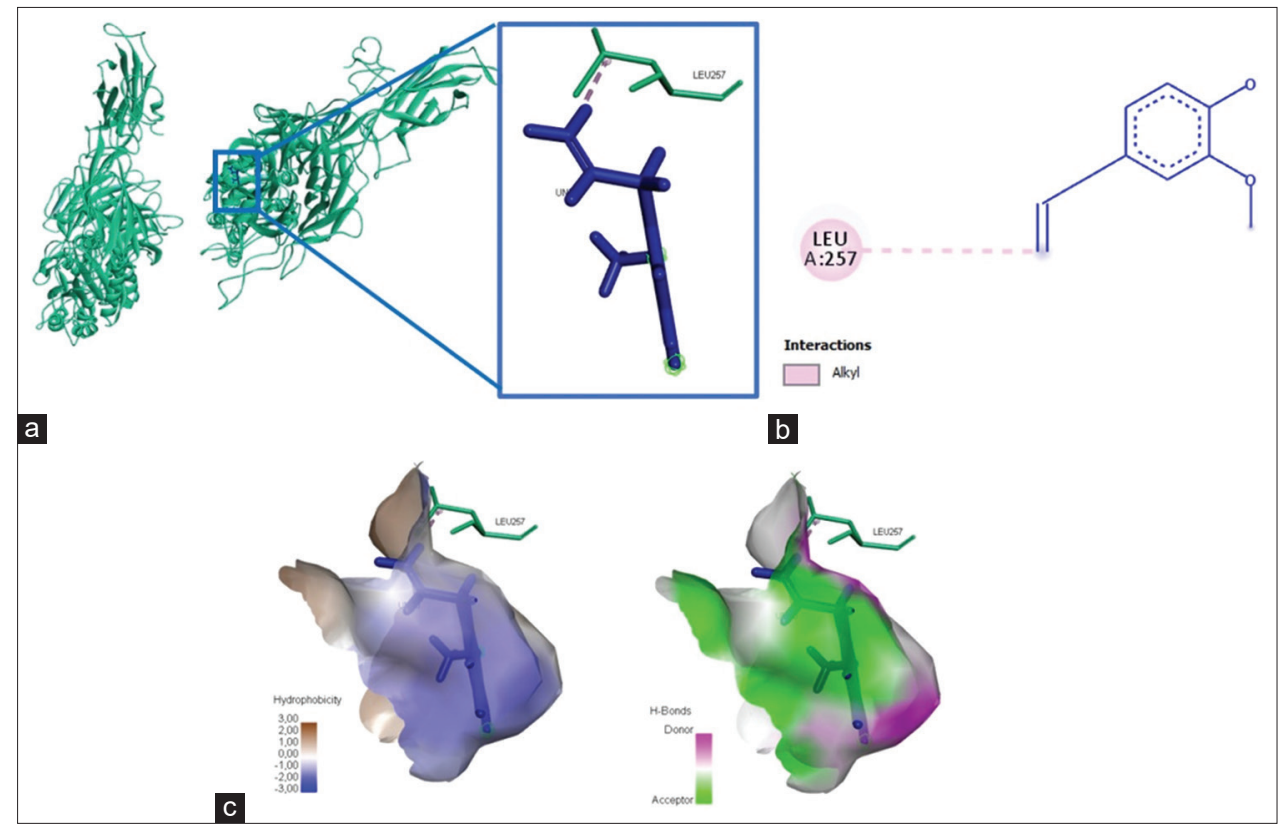

Figure-7: The visualization of the three-dimensional and two-dimensional interaction between phenolic compounds (eugenol) and integrin $\alpha 5 \beta 1$. (a) Three-dimensional structural interaction between phenol-ligand eugenol (blue) and integrin $\alpha 5 \beta 1$ (green). (b) This interaction is built by alkyl interactions (pink) on the active site of the $\alpha 5 \beta 1$ integrin, namely, Leu257, which is seen in the two-dimensional (b) three-dimensional (c) structures.

effect in human A549 cells, demonstrated by the percent-mean viability decrement in a concentration-dependent manner similar to cisplatin, and compared with the untreated control. The optimal concentration of EEOS was $200 \mu \mathrm{g} / \mathrm{mL}$; at this EEOS concentration, there was a smaller number of viable A549 cells than the number seen with other concentrations of EEOS $(50,70$, and $100 \mu \mathrm{g} / \mathrm{mL})$ (Figures-11 and 12).

\section{Discussion}

Lung cancer remains the leading cause of cancer death in men and women worldwide [12]. In the past few years, the use of herbal medicine has continued to increase; currently, it is a trend to use herbal medicines concurrently with traditionally established treatments for cancer. One of the most 


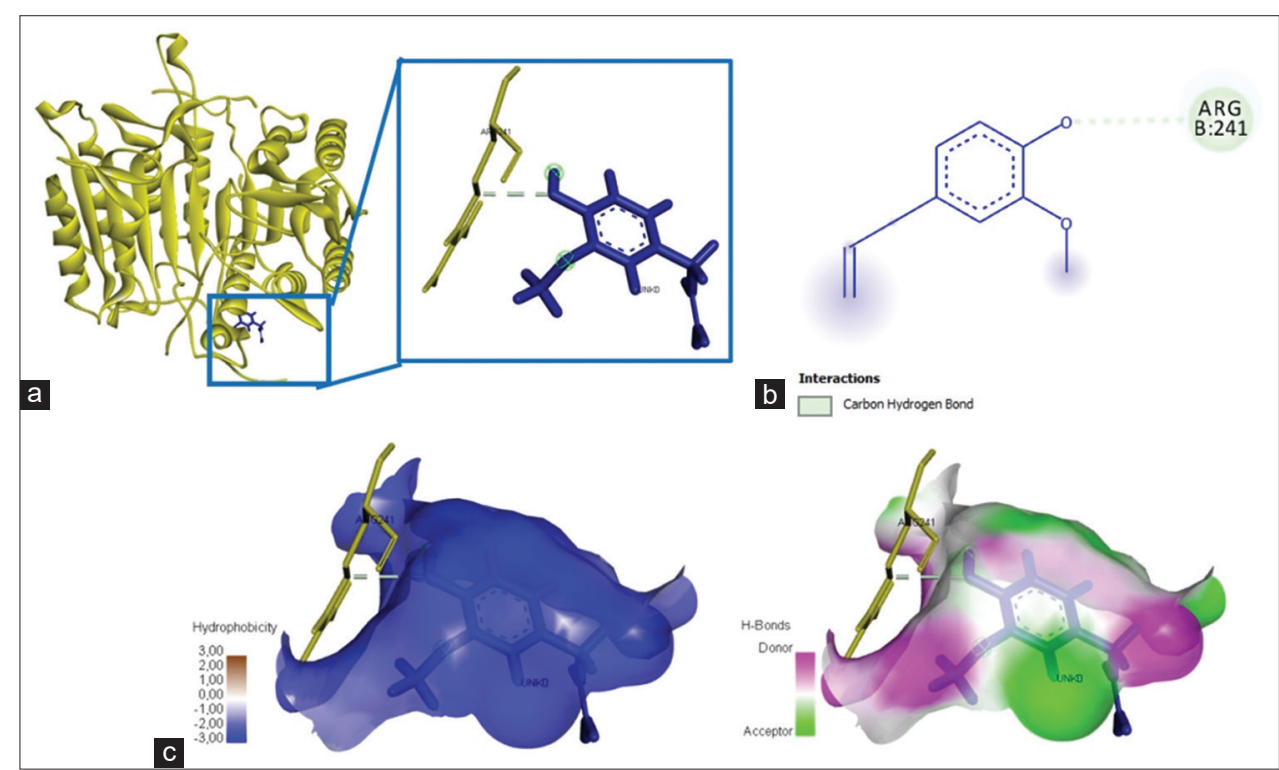

Figure-8: The visualization of the three-dimensional and two-dimensional interaction between phenolic compounds (eugenol) and caspase-3. (a) Three-dimensional structural interaction between the ligand eugenol (blue) and caspase-3 (yellow). (b) This interaction is established by hydrophobic hydrogen bonds on the active site of caspase-3, namely, Arg241, which is seen in the two-dimensional (b) and three-dimensional (c) structures.

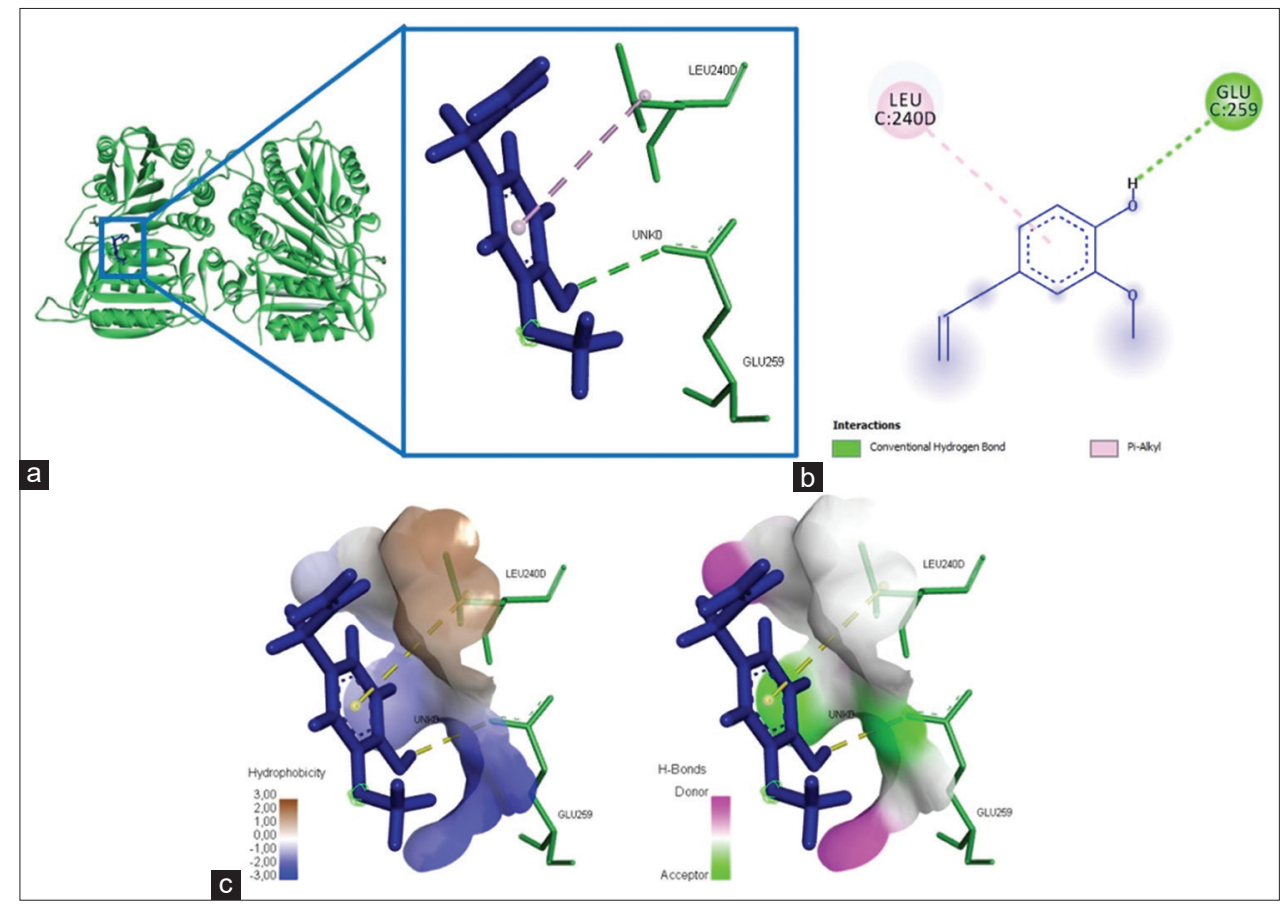

Figure-9: The visualization of the three-dimensional and two-dimensional interaction between phenolic compounds (eugenol) and caspase-9. (a) Three-dimensional structural interaction between the ligand eugenol (blue) and caspase-9 (green). (b) This interaction is established by hydrophobic hydrogen bonds on the active site of caspase-9, namely, Glu259 and Leu240, which can be seen in the two-dimensional (b) and three-dimensional (c) structures.

popular herbs for medicinal uses is $O$. sanctum Linn.; however, not much has been known about its use in the treatment of lung cancer. In this current study, we used in silico molecular docking and in vitro approaches to determine the mechanism of action of the EEOS.

Spectrophotometry analysis showed that EEOS contained two primary compounds, that is, quercetin and eugenol, belonging to the flavonoid group and the phenol group, respectively (Table-1). Some research has shown that natural sources (eugenol, caffeic acid, gallic acid, apigenin, quercetin, and rosmarinic acid) have therapeutic benefits in treating various diseases, including cancer [13-17]. In silico molecular docking, analysis showed that quercetin and eugenol were able to bind to the active site of the avb3 integrin (Arg99, Arg261, Tyr224, Lys409, Ser342, Tyr406, and Arg261) and a5b1 integrin (Thr258, Gly255, Asn256, Leu257, Ser277, and Leu257). Integrins are known to play a crucial role in mediating the adhesion of epithelial 


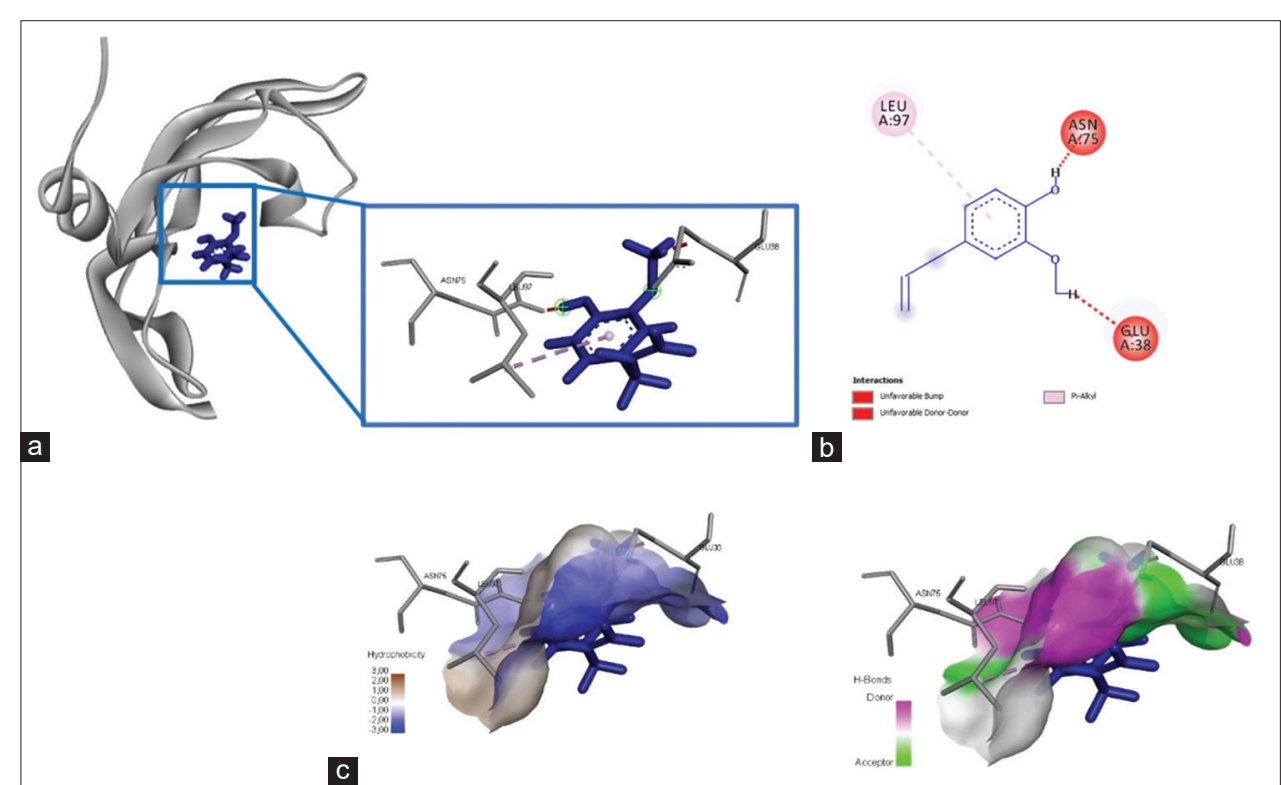

Figure-10: The visualization of the three-dimensional and two-dimensional interaction between phenol compounds (eugenol) and vascular endothelial growth factor (VEGF). (a) Three-dimensional structural interaction between the ligand eugenol (blue) and VEGF (gray). (b) This interaction is built by hydrophobic hydrogen bonds on the active site of VEGF, namely, Leu97, Glu38, Asn75, which can be seen in the two-dimensional (b) and three-dimensional (c) structures.

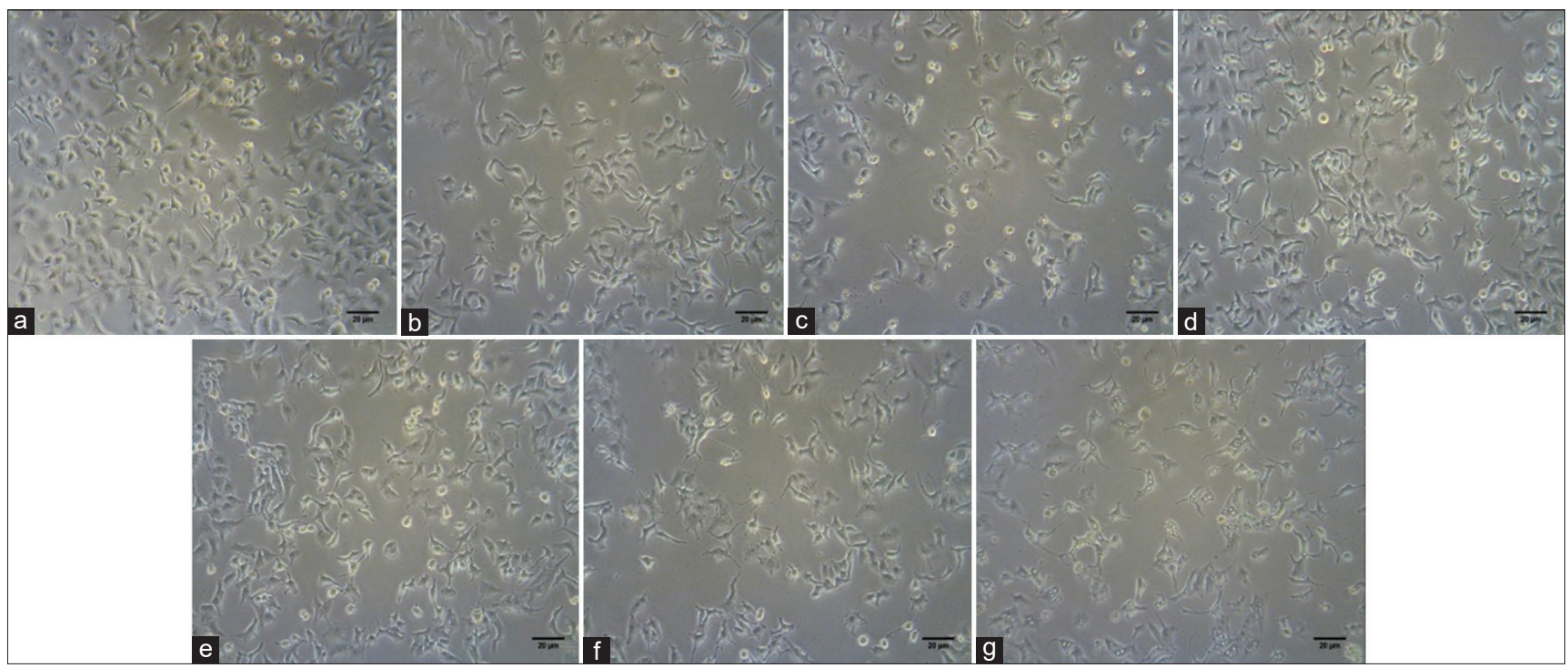

Figure-11: (a-g) A photomicrograph of the non-small cell lung cancer (NSCLC) (A549) cells' viability. NSCLC (A549) cells were treated.

cells to basement membranes. They also contribute to the migration, proliferation, and survival of tumor cells [18]. Furthermore, tumor cell expression of the integrins av $\beta 3$, a5 $\beta 1$, a6 $\beta 4$, a $4 \beta 1$, and $\mathrm{v} \beta 6$ correlates with disease progression in various tumor types and is associated with cancer [18-20]. The adhesion of integrins to the extracellular matrix (ECM) provides the necessary traction for tumor cells' invasion. Integrins contribute to tumor cells' invasion by regulating the localization and activity of matrix-degrading proteases, such as matrix metalloprotease 2 (MMP2) and urokinase-type plasminogen activator (uPA). Integrinmediated migration generally requires focal adhesion kinase and Src family kinase signaling $[18,21,22]$. Cancer treatment could be promoted by inhibiting the activity of the integrin complex [22,23]. In addition, integrins physically associate laterally with cell membrane proteins (e.g., CD151 or CD47) to elicit or modulate signaling $[24,25]$. Data from this study indicated the potential for inhibition by the ligand on the integrin avb3 and integrin a5 $\beta 1$ proteins. Inhibition of the integrin complex would impact the inhibition of the extracellular matrix adhesion (ECM) process and limit tumor cells' invasion. In addition, inhibition of the process and activity of proteases and activators may occur. As a result, endothelial and epithelial cells rapidly undergo anoikis followed by inflammation and apoptosis when adhesion is disturbed [26,27]. The excessive growth of cancer cells is thus kept in check.

In addition, in silico molecular docking revealed the interaction between quercetin and eugenol with the active sites of VEGF, at positions Gln79, Pro49, 


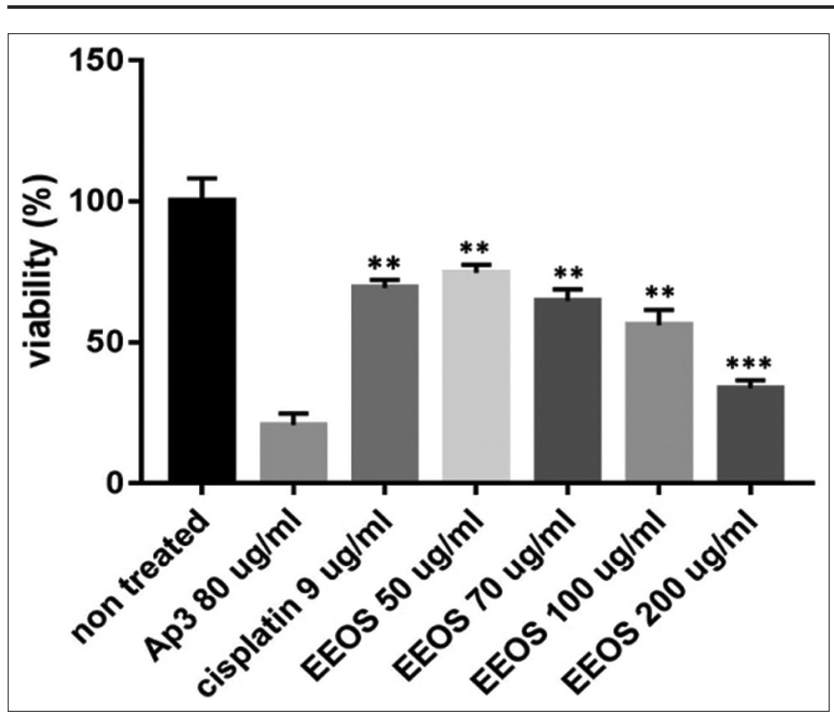

Figure-12: The inhibitory and antiproliferative effect of the ethanolic extract from Ocimum sanctum Linn. (EEOS) against non-small cell lung cancer (A549) cells. The cells were cultivated in the presence of an inhibitor (AP3) as the positive control, cisplatin as the commercial drug comparison, and EEOS at concentrations of 50, 70, 100, and $200 \mu \mathrm{g} / \mathrm{mL}$. After 24 h, EEOS's inhibitory effect was visualized by an MTT reagent at a wavelength of $595 \mathrm{~nm}$ (NT: Non-treated; ** significant $\mathrm{p}<0.0072 ; * * *$ significant $\mathrm{p}<0.0002 ;$ n.s. $=$ Not significant).

Lys48, Leu97, Glu38, and Asn75. VEGF is a very potent pro-angiogenesis factor in the growth process of cancer cells that modulate the proliferation and migration of cancer cells [28]. In lung cancer, VEGF is overexpressed and plays an essential role in cancer cells' growth and modulates other pro-angiogenic factors [12]. The binding between the active compounds in EEOS and the VEGF site through conventional hydrogen bonds is expected to inhibit the activity and stimulation. Our data are in line with the previous studies showing that the binding between VEGFB and VEGFR on the Pro143, Leu204, Phe172, Lys170, Pro173, Leu174, Lys171, Thr206, Glu208, Leu215, and Lys 217 was able to inhibit interaction with the extracellular matrix. It is also known that silico molecular docking phytocompounds such as eriodyctiol, epicatechin, scutellarin, and ginkgolide A can bind to VEGF with tremendous energy as standard drugs for the 4T1 mammary carcinoma cell line [29,30]. We determined that the binding of eugenol and quercetin to VEGF resulted from the interaction of conventional hydrogen bonds and Pi-cation, Pi-sigma, and Pi-alkyl interactions, which significantly contributed to the stability of the bond structure [31-34]. Moreover, the binding interaction also supported the hydrogen's donor and acceptor abilities and thus may predict the antioxidant activity of quercetin and eugenol [16,35].

Furthermore, if EEOS was able to inhibit $\alpha v \beta 3$, $\alpha 5 \beta 1$, and VEGF, would EEOS also be able to induce apoptotic activity? Based on our molecular docking, it was found that quercetin and eugenol were able to interact with the active sites of caspase-3 and caspase-9 proteins, Thr270, Arg241, Thr152, Gly153, Lys271, and Ile187 and Glu187, Glu259, and Leu240, respectively. The key to EEOS's pharmacological properties is its binding to the active site through conventional hydrogen bonds and Pi-cation, Pi-sigma, and Pi-alkyl interactions with amino acid residues in caspase-3 and caspase-9 proteins. Our in silico research found that quercetin and eugenol form stronger bonds in caspase- 9 than caspase-3. Based on this binding, we postulated that EEOS could directly induce conformational changes in caspase- 3 and caspase- 9 to mature caspase- 3 or cleaved caspase-3/caspase- 9 to increase PARP's cleavage activity, followed by anoikis, which, in turn, initiates apoptosis. Our results were consistent with the previous studies using natural ingredients, namely, chalcone $9 \mathrm{X}$, in silico, to induce conformational changes in caspase- 8 and caspase- 3 to initiate apoptosis [35].

In accordance with the results of the in silico molecular docking, we performed an in vitro analysis. The in vitro results were consistent with the in silico data showing that the main contents of EEOS, namely, flavonoids and eugenol, were able to inhibit cells' attachment to the extracellular matrix. EEOS may thus inhibit the adhesion of the NSCLC (A549) cells in the same way the conventional commercial drug cisplatin (used in this experiment) does. EEOS's mechanism of action may inhibit adhesion, invasion, and cell migration, thus triggering anoikis and apoptosis in the A549 cell line.

\section{Conclusion}

Our data revealed that EEOS could act as both an antiproliferative and apoptotic agent on NSCLC cells in in silico molecular docking and in vitro experiments. Nevertheless, further investigation of the mechanism, dosage, and other potential benefits of EEOS as a possible herbal medication to prevent NSCLC is needed.

\section{Authors' Contributions}

UK and TSDR: Experimental work and data analysis. NDAA: Literature study and wrote the manuscript. HW: Design of the experiment, literature study, wrote the concept of the original manuscript, and reviewing and editing of the final manuscript. DLK: Writing, reviewing, and editing of the manuscript. All authors read and approved the final manuscript.

\section{Acknowledgments}

The authors are thankful to the Department of Pharmacology, Faculty of Medicine, Universitas Gadjah Mada, and Ms. Mosa for excellent technical assistance. This study was funded by the Ministry of Education, Culture, Research and Technology of the Republic of Indonesia through Basic Research Grant (Grant Number: 2173/UN1/DITLIT/DIT-LIT/ PT/2021).

\section{Competing Interests}

The authors declare that they have no competing interests. 


\section{Publisher's Note}

Veterinary World remains neutral with regard to jurisdictional claims in published institutional affiliation.

\section{References}

1. Bray, F., Ferlay, J., Soerjomataram, I., Siegel, R.L., Torre, L.A. and Jemal, A. (2018) Global cancer statistics 2018: GLOBOCAN estimates of incidence and mortality worldwide for 36 cancers in 185 countries. CA Cancer J. Clin., 68(6): 394-424.

2. Gao, Y., Dorn, P., Liu, S., Deng, H., Hall, S.R.R., Peng, R.W., Schmid, R.A. and Marti, T.M. (2019) Cisplatin-resistant A549 non-small cell lung cancer cells can be identified by increased mitochondrial mass and are sensitive to pemetrexed treatment. Cancer Cell Int. 19(1): 317.

3. Onuki, T., Morita, E., Sakamoto, N., Nagai, Y., Sata, M. and Hagiwara, K. (2018) Severe upper gastrointestinal disorders in pembrolizumab-treated non-small cell lung cancer patient. Respirol. Case Rep., 6(6): e00334.

4. Park, J., Jeong, D., Song, M. and Kim, B. (2021) Recent advances in anti-metastatic approaches of herbal medicines in 5 major cancers: From traditional medicine to modern drug discovery. Antioxidants 10(4): 527.

5. Yoon, S., Han, J.J., Baek, S.K., Kim, H.J. and Maeng, C.H. (2020) Prembolizumab-induced severe oral mucositis in a patient with squamous cell carcinoma of lung: A case study. Lung Cancer, 147: 21-25.

6. Mataram, M.B.A., Hening, P., Harjanti, F.N., Karnati, S., Wasityastuti, W., Nugrahaningsih, D.A.A., Kusindarta, D.L. and Wihadmadyatami, H. (2021) The neuroprotective effect of ethanolic extract Ocimum sanctum Linn. in the regulation of neuronal density in hippocampus areas as a central autobiography memory on the rat model of Alzheimer's disease. J. Chem. Neuroanat., 111: 101885.

7. Kusindarta, D.L., Wihadmadyatami, H., Jadi, A.R., Karnati, S., Lochnit, G., Hening, P., Haryanto, A., Auriva, M.B. and Purwaningrum, M. (2018) Ethanolic extract Ocimum sanctum. Enhances cognitive ability from young adulthood to middle-aged mediated by increasing choline acetyltransferase activity in rat model. Res. Vet. Sci., 118: 431-438.

8. Raditya, M.N., Bagus, A.M.M., Kustiati, U., Wihadmadyatami, H. and Kusindarta, D.L. (2020) Data of the expression of serotonin in Alzheimer's disease (AD) rat model under treatment of ethanolic extract Ocimum sanctum Linn. Data Br., 30(4): 105654.

9. Kusindarta, D.L., Wihadmadyatami, H. and Haryanto, A. (2016) Ocimum sanctum Linn. stimulate the expression of choline acetyltransferase on the human cerebral microvascular endothelial cells. Vet. World, 9(12): 1348-1354.

10. Kusindarta, D.L., Wihadmadyatami, H. and Haryanto, A. (2018) The analysis of hippocampus neuronal density (CA1 and CA3) after Ocimum sanctum ethanolic extract treatment on the young adulthood and middle age rat model. Vet. World, 11(2): 135-140.

11. Kumar, V., MarkoviĆ, T., Emerald, M., Dey, A. (2015) Herbs: Composition and dietary importance. Encycl. Food Health, 3(3): 332-337.

12. Frezzetti, D., Gallo, M., Maiello, M.R., D'Alessio, A., Esposito, C., Chicchinelli, N., Normanno, N. and De Luca, A. (2017) VEGF as a potential target in lung cancer. Expert Opin. Ther. Targets, 21(10): 959-966.

13. Tang, S.M., Deng, X., Zhou, J., Li, Q.P., Ge, X.X. and Miao, L. (2020) Pharmacological basis and new insights of quercetin action in respect to its anticancer effects. Biomed. Pharmacother., 121: 32.

14. Vafadar, A., Shabaninejad, Z., Movahedpour, A., Fallahi, F., Taghavipour, M., Ghasemi, Y., Akbari, M., Shafiee, A., Hajighadimi, S., Moradizarmehri S., Razi, E.,
Savardashtaki, A. and Mirzaei, H. (2020) Quercetin and cancer: New insights into its therapeutic effects on ovarian cancer cells. Cell Biosci., 10: 1-17.

15. Abdullah, M.L., Hafez, M.M., Al-Hoshani, A. and Al-Shabanah, O. (2018) Anti-metastatic and antiproliferative activity of eugenol against triple-negative and HER2 positive breast cancer cells. BMC Complement Altern. Med., 18(1): 1-11.

16. Bezerra, D.P., Militão, G.C.G., De Morais, M.C., De Sousa, D.P. (2017) The dual antioxidant/prooxidant effect of eugenol and its action in cancer development and treatment. Nutrients, 9(12): 1-15.

17. Ezzati, M., Yousefi, B., Velaei, K. and Safa, A. (2020) A review on anticancer properties of quercetin in breast cancer. Life Sci., 248: 117463.

18. Desgrosellier, J.S. and Cheresh, D.A. (2010) Integrins in cancer: Biological implications and therapeutic opportunities. Nat. Rev. Cancer, 10(1): 9-22.

19. Aksorn, N. and Chanvorachote, P. (2019) Integrin as a molecular target for anticancer approaches in lung cancer. Anticancer Res., 39(2): 541-548.

20. Seyed, M.A., Jantan, I., Bukhari, S.N.A. and Vijayaraghavan, K. (2016) A comprehensive review on the chemotherapeutic potential of piceatannol for cancer treatment, with mechanistic insights. J. Agric. Food Chem., 64(4): 725-737.

21. Bianconi, D., Unseld, M. and Prager, G.W. (2016) Integrins in the spotlight of cancer. Int. J. Mol. Sci., 17(12): 2037.

22. Hamidi, H. and Ivaska, J. (2018) Every step of the way: Integrins in cancer progression and metastasis. Nat. Rev. Cancer, 18(9): 533-548.

23. Hamidi, H., Pietilä, M. and Ivaska, J. (2016) The complexity of integrins in cancer and new scopes for therapeutic targeting. Br. J. Cancer, 115(9): 1017-1023.

24. Alday-Parejo, B., Stupp, R. and Rüegg, C. (2019) Are Integrins Still Practicable Targets for anti-cancer therapy? Cancers (Basel), 11(7): 978.

25. Vicente-Manzanares, M. and Sánchez-Madrid, F. (2018) Targeting the integrin interactome in human disease. Curr. Opin. Cell Biol., 55(10): 17-23.

26. Santoso, S., Wihadmadyatami, H., Bakchoul, T., Werth, S., Al-Fakhri, N., Bein, G., Kiefel, V., Zhu, J., Newman, P.J., Bayat, B. and Sachs, U.J. (2016) Antiendothelial $\alpha v \beta 3$ antibodies are a major cause of intracranial bleeding in fetal/neonatal alloimmune thrombocytopenia. Arterioscler Thromb. Vasc. Biol., 36(8): 1517-1524.

27. Danen, E.H.J. (2013) Integrin signaling as a cancer drug target. ISRN Cell Biol., 2013(7): 135164.

28. Li, D., Xie, K., Zhang, L., Yao, X., Li, H., Xu, Q., Wang, X., Jiang, J. and Fang, J. (2016) Dual blockade of vascular endothelial growth factor (VEGF) and basic fibroblast growth factor (FGF-2) exhibits potent antiangiogenic effects. Cancer Lett., 377(2): 164-173.

29. Sadremomtaz, A., Ali, A.M., Jouyandeh, F., Balalaie, S., Navari, R., Broussy, S., Mansouri, K., Groves, M.R. and Asghari, S.M. (2020) Molecular docking, synthesis and biological evaluation of vascular endothelial growth factor (VEGF) B based peptide as antiangiogenic agent targeting the second domain of the vascular endothelial growth factor receptor 1 (VEGFR1D2) for anticancer applicant. Signal Transduct. Target Ther., 5(1): 3-6.

30. Lutfiya, A.S., Priya, S., Manzoor, M.A.P. and Hemalatha, S. (2019) Molecular docking and interactions between vascular endothelial growth factor (VEGF) receptors and phytochemicals: An in-silico study. $B C A B$, 2(11): 101424 .

31. Bare, Y., Sari, D.R.T., Rachmad, Y.T., Krisnamurti, G.C. and Elizabeth, A. (2019) In silico insight the prediction of chlorogenic acid in coffee through cyclooxygenase-2 (COX2) interaction. Biog. J. Ilm. Biol., 7(2): 100-105.

32. Martin, K.R. (2006) Targeting apoptosis with dietary 
bioactive agents. Exp. Biol. Med., 231(2): 117-129.

33. Sari, D.R.T., Cairns, J.R.K., Safitri, A. and Fatchiyah, F. (2019) Virtual prediction of the delphinidin-3-o-glucoside and peonidin-3-o-glucoside as anti-inflammatory of TNF- $\alpha$ signaling. Acta Inform. Med., 27(3): 152-157.

34. Wang, X., Yang, Y., An, Y. and Fang, G. (2019) The mechanism of anticancer action and potential clinical use of kaempferol in the treatment of breast cancer. Biomed. Pharmacother., 117(9): 1-16.

35. Dong, N., Liu, X., Zhao, T., Wang, L., Li, H., Zhang, S., Li, X., Bai, X., Zhang, Y. and Yang, B. (2018) Apoptosisinducing effects and growth inhibitory of a novel chalcone, in human hepatic cancer cells and lung cancer cells. Biomed. Pharmacother., 105(9): 195-203.

$* * * * * * * *$ 